\title{
Anthropogenic Impacts on Meiosis in Plants
}

\author{
Lorenz K. Fuchs, Glyn Jenkins and Dylan W. Phillips* \\ Institute of Biological, Environmental and Rural Sciences, Aberystwyth University, Aberystwyth, United Kingdom
}

As the human population grows and continues to encroach on the natural environment, organisms that form part of such ecosystems are becoming increasingly exposed to exogenous anthropogenic factors capable of changing their meiotic landscape. Meiotic recombination generates much of the genetic variation in sexually reproducing species and is known to be a highly conserved pathway. Environmental stresses, such as variations in temperature, have long been known to change the pattern of recombination in both model and crop plants, but there are other factors capable of causing genome damage, infertility and meiotic abnormalities. Our agrarian expansion and our increasing usage of agrochemicals unintentionally affect plants via groundwater contamination or spray drift; our industrial developments release heavy metals into the environment; pathogens are spread by climate change and a globally mobile population; imperfect waste treatment plants are unable to remove chemical and pharmaceutical residues from sewage leading to the release of xenobiotics, all with potentially deleterious meiotic effects. In this review, we discuss the major classes of exogenous anthropogenic factors

OPEN ACCESS

Edited by:

Tomás Naranjo,

Complutense University of Madrid,

Spain

Reviewed by:

Ahmad Arzani,

Isfahan University of Technology, Iran

María-Dolores Rey,

Universidad de Córdoba, Spain

*Correspondence:

Dylan W. Phillips

dwp@aber.ac.uk

Specialty section:

This article was submitted to

Plant Cell Biology,

a section of the journal

Frontiers in Plant Science

Received: 29 June 2018 Accepted: 07 September 2018 Published: 28 September 2018

Citation:

Fuchs $L K$, Jenkins $G$ and Phillips DW (2018) Anthropogenic Impacts on Meiosis in Plants.

Front. Plant Sci. 9:1429. doi: 10.3389/fpls.2018.01429 known to affect meiosis in plants, namely environmental stresses, agricultural inputs, heavy metals, pharmaceuticals and pathogens. The possible evolutionary fate of plants thrust into their new anthropogenically imposed environments are also considered.

Keywords: anthropogenic, meiosis, recombination, plants, pollution, evolution

\section{INTRODUCTION}

Humanity's impact on natural ecosystems is well documented and has led to a decline in biodiversity globally (Cardinale et al., 2012; Hautier et al., 2015). The anthropogenic drivers responsible for this are predominantly related to climate change and pollution that stem from the agricultural and industrial demand to support an ever-growing population. These factors are also known to effect cellular processes, meiosis being particularly vulnerable. The meiotic process is key for all sexually reproducing organisms as it is responsible for halving the chromosome number during gametogenesis and for the process of recombination which generates much of the genetic diversity. The biochemical processes underpinning meiosis are highly conserved but can be influenced by both abiotic and biotic stresses (Modliszewski and Copenhaver, 2017).

Atmospheric and terrestrial pollutants, and xenobiotic compounds (defined as any nonbiological compounds that have a detrimental effect on the organism) are prevalent in the environment. The actual number of such compounds is difficult to ascertain accurately, but the United States Environmental Protection Agency currently lists over 85,000 substances on their Toxic Substances Control Act Chemical Substance Inventory (Donner et al., 2010; European Psychiatric Association [EPA], 2018 $)$. The genotoxicity of such compounds on plants has been assayed using a variety of methods and a range of plants species including Tradescantia paludosa,

\footnotetext{
${ }^{1}$ https://www.epa.gov/tsca-inventory
} 
Allium cepa, and Vicia faba (Kristen, 1997). The assays involve exposing plants to a known pollutant and assaying the number of chromosome aberrations induced. Initially, assays utilized root cells undergoing mitosis but it was later realized that meiotic cells were far more sensitive to such compounds (Kristen, 1997). The most widely used assay is the Tradescantia Micronucleusin-Tetrad Assay for Environmental Mutagenesis, commonly referred to as the Trad-MCN assay (Rodrigues et al., 1997). The Trad-MCN assay detects micronuclei formed during meiosis, and has been used for in situ and in vivo laboratory tests to determine the genotoxicity of pollutants in the air, water and soil. The sensitivity of this assay is staggering; for example, plants exposed to various brands of air fresheners for between to 1-6 h results in a significantly higher number of micronuclei (Ma and Harris, 1987a,b). Such assays emphasize the sensitivity of meiosis to external factors.

In some instances, it is desirable to alter the meiotic process, and there has been a resurgence in interest to modulate the recombination landscape in crop plants in order to increase genetic variability for selection in advanced breeding programs. The benefit to plant breeding is clear, but for non-crop plants such destabilizing factors could be detrimental and could confer selective disadvantage. The aim of this review is to examine anthropogenic factors such as climate, agrochemicals, heavy metals, combustible gasses, pharmaceuticals and pathogens, which are known to influence meiosis in a range of plant species (summarized in Table 1).

\section{ENVIRONMENTAL STRESSES}

It is now generally accepted that human activity is responsible for climate change (International Plant Protection Convention [IPPC], 2014), which is manifested as a rise in global temperature and carbon dioxide levels, more extreme and unpredictable weather patterns, and a rise in sea levels with its concomitant increased risk of salinisation of ground water. These changes are very likely to challenge our agricultural productivity and threaten global food security. As a consequence, it is imperative that we understand the plant's response to abiotic stresses, as this will inform our strategies of intervention to protect and adapt future crops (Mickelbart et al., 2015). This section focusses upon the effects of environmental stresses on meiosis and recombination in some model, crop and noncrop species. It is pertinent to consider this process in this context, since recombination is fundamental to the fertility, genetic stability and genetic potential of sexually reproducing organisms.

Through exhaustive investigation, we now have a very good idea of how meiosis works (Wang and Copenhaver, 2018), and how external stresses may invoke certain adaptive and ameliorative responses in plants (De Storme and Geelen, 2014; Bomblies et al., 2015; Modliszewski and Copenhaver, 2017). Suboptimal high and low growth temperatures and their effects on modulating crossover (CO) frequency and distribution in plants have received particular attention, and have long been recognized in plants. In most instances, such adjustments in
CO landscape have been inferred from observing chiasmata, the cytological equivalents of COs at metaphase I. Elliott (1955) showed that there was a reduction of $\mathrm{CO}$ frequency in meiosis in Endymion nonscriptus at $20^{\circ} \mathrm{C}$ but not between 1 and $15^{\circ} \mathrm{C}$. These observations are not consistent with a subsequent study, which showed a consistent but gradual decrease in mean chiasma frequency with increasing temperature in this species (Wilson, 1959b). This difference could be explained by genetic and environmental influences beyond temperature. Dowrick (1957) recorded an increase in interstitial chiasmata with increasing temperature in T. bracteata and Uvularia perfoliata, Elliott (1955) showed a detrimental effect on chiasma frequency at $20^{\circ} \mathrm{C}$ in Hyacinthus orientalis, and Lin (1982) showed that chiasma frequency is reduced at $37^{\circ} \mathrm{C}$ in Rhoeo spathacea. A combination of water and temperature stress in two varieties of Hemerocallis induces desynapsis (Karihaloo, 1986, 1994). High temperature induces meiotic irregularities and diploid pollen formation in species of Rosa (Pecrix et al., 2011) and Populus (Wang et al., 2017; Tian et al., 2018), which is considered to have important implications in terms of adaptation and evolution through polyploidisation. Recombination frequencies in Arabidopsis thaliana are positively correlated with temperature over the range $19-28^{\circ} \mathrm{C}$ (Francis et al., 2007), but this response appears to be part of a U-shaped curve in which chiasma frequencies rise from a low at $18^{\circ} \mathrm{C}$ to higher values at both 8 and $28^{\circ} \mathrm{C}$ (Lloyd et al., 2018). The changes involve class I interfering COs only (Modliszewski et al., 2018), in contrast to the observations in barley (Hordeum vulgare) described below.

The studies above describe temperature effects on recombination in non-crop species. Whilst these have value in forwarding our knowledge and understanding of fundamental biological processes, they cannot substitute for studying these effects in the crops themselves, especially given the variation in responses of different plants, which confounds direct translation from one species to another. Unfortunately, there is a dearth of systematic studies of this phenomenon in crop plants, but several particular crops stand out. Prakken (1943) showed that high temperature and drought together exacerbated reduced bivalent formation in asynaptic rye, and Saini et al. (1984) showed that temperature and water stress together caused male sterility in wheat, but not through any demonstrable negative effect on meiosis. The latter contrasts with more recent observations, which show that heat stress induces meiotic chromosomal abnormalities in four wheat cultivars, and various changes in meiotic defects in some cereal crops (Rezaei et al., 2010; Omidi et al., 2014). Si et al. (2015) showed that some but not all rice (Oryza sativa) plants subjected to heat stress had higher recombination frequencies. Powell and Nilan (1963) described by cytology significantly higher chiasma frequencies at higher temperatures in an inversion heterozygote of barley. In contrast, Jensen (1981) used genetic mapping of barley to show that temperatures of 12,18 , and $24^{\circ} \mathrm{C}$ had no effect on recombination frequencies. Higgins et al. (2012) later reported that a rise in temperature not only increases the $\mathrm{CO}$ frequency, but also redistributes COs to more distal chromosomal locations. Since COs are highly distally localized 
TABLE 1 | Summary of anthropogenic factors and their influence on meiosis.

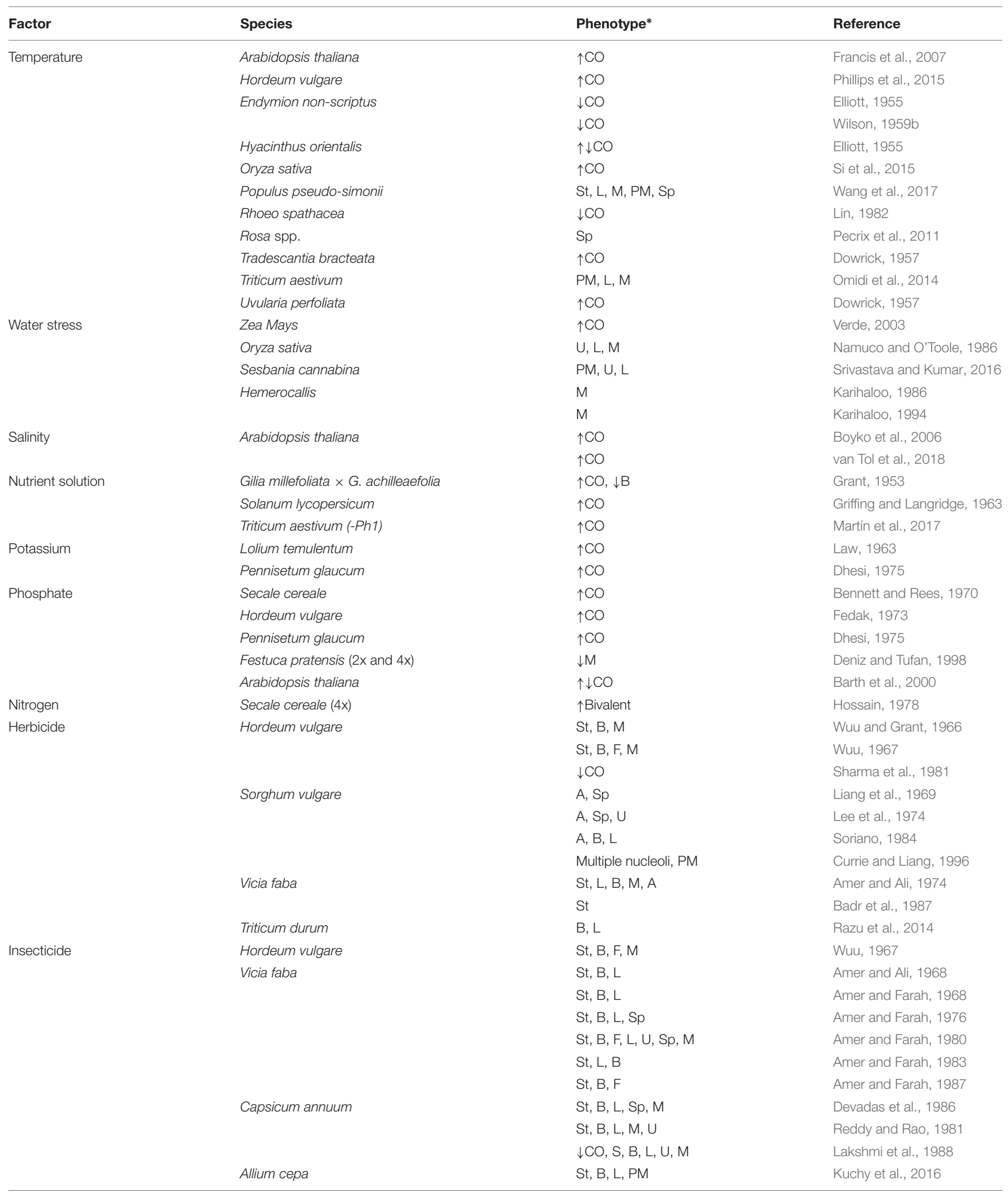


TABLE 1 | Continued

\begin{tabular}{|c|c|c|c|}
\hline Factor & Species & Phenotype* & Reference \\
\hline \multirow[t]{9}{*}{ Fungicide } & Hordeum vulgare & St, B, F, M & Wuu, 1967 \\
\hline & & $\downarrow \mathrm{CO}$ & Bennett, 1971 \\
\hline & & $\downarrow \mathrm{CO}$ & Sharma et al., 1983 \\
\hline & Allium cepa & St, B, F, M & Mann, 1977 \\
\hline & & St, B, L, M & Fisun and Rasgele, 2009 \\
\hline & & St, B, L, PM & Kuchy et al., 2016 \\
\hline & Pisum sativum & $\uparrow \downarrow C O$ & Choudhary and Sajid, 1986 \\
\hline & Capsicum annuum & St, B, L, U, multivalents & Prakash et al., 1988 \\
\hline & Lathyrus sativus & $\mathrm{S}, \mathrm{B}, \mathrm{L}, \mathrm{F}, \mathrm{U}$ & Kumar and Sinha, 1991 \\
\hline \multirow[t]{8}{*}{ Heavy Metals } & Glycine max & St, L, U, B, PM & Kumar, 2007 \\
\hline & Zea mays & $\mathrm{PM}, \mathrm{B}, \mathrm{L}, \mathrm{U}, \mathrm{F}, \mathrm{M}$ & Kumar and Rai, 2010 \\
\hline & Vicia faba & St, L, B & George, 2000 \\
\hline & Hordeum vulgare & PM, L, B, M & Mittal and Srivastava, 2014 \\
\hline & Lathyrus sativus & $\cup, \downarrow C O$ & Kumar and Ritambhara, 2006 \\
\hline & & St, Sp, L & Tripathi and Girjesh, 2010 \\
\hline & Capsicum annuum & St, PM, L, B, F, M & Aslam et al., 2017 \\
\hline & Vicia faba & S, St, L, B & George, 2000 \\
\hline \multirow[t]{2}{*}{ Caffeine } & Secale cereale & $\mathrm{L}, \mathrm{B}, \downarrow \mathrm{CO}$ & de la Peña et al., 1981 \\
\hline & Trigonella foenum-graecum & $\mathrm{L}, \mathrm{B}, \mathrm{U}, \mathrm{St}, \mathrm{PM}$ & Anis and Wani, 1997 \\
\hline \multirow[t]{7}{*}{ Pathogen } & Oryza sativa & $\uparrow \mathrm{CO}$ & Si et al., 2015 \\
\hline & Carica papaya & $L, B, \cup$ & Pandey, 2017 \\
\hline & Datura quercifolia & $\downarrow C O, U, L, M$ & Kaul, 1968 \\
\hline & Solanum lycopersicum & PM, A & Caldwell, 1952 \\
\hline & Capsicum annuum & $\downarrow \mathrm{CO}, \mathrm{Sp}$ & Swaminathan et al., 1959 \\
\hline & Lycopersicon esculentum & $\mathrm{B}, \mathrm{PM}, \mathrm{M}, \mathrm{F}$ & Andronic, 2012 \\
\hline & Hordeum vulgare & $B, P M, L$ & Andronic, 2012 \\
\hline \multirow[t]{2}{*}{ Antibiotics } & Allium cepa & St, L, P, B, F & Mann, 1978 \\
\hline & Lathyrus sativus & U, St, B & Kumar and Sinha, 1991 \\
\hline
\end{tabular}

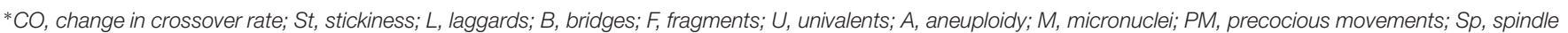
aberrations. $\uparrow$ denotes increase, $\downarrow$ denotes decrease.

in this species, this phenomenon has important implications for cracking open tight linkage groups, which are otherwise refractory to recombination events. These observations were confirmed by a subsequent study (Phillips et al., 2015), which went on to show that high temperature increases only class II CO frequency in male meiosis, and also demonstrated that interstitial regions of the genome are more prone to these changes. There is a tantalizing prospect, therefore, that simple heat shocking of barley at vulnerable stages of development could release potentially useful genetic variation for use in advanced breeding programs. However, this is predicated upon a greater understanding of the genetic (see review by Wang and Copenhaver, 2018) and epigenetic processes (reviewed by Yelina et al., 2015) underpinning these effects, which could ultimately enable the precise reprogramming of the crop.

The variation in response to temperature, even within the same species, may indicate that there is plasticity in the mechanisms governing $\mathrm{CO}$ control, or may implicate alternative pathways with different mechanisms. A caveat is that these differences may simply reflect discrepancies in the methods used to acquire and compare data, as has been inferred by (Wilson, 1959a; Bomblies et al., 2015; Lloyd et al., 2018).
Whilst temperature effects on recombination are the most widely described in the literature, there is some information describing other abiotic factors of relevance to climate change. Water stress has been shown to cause meiotic chromosome abnormalities in rice, such as laggards, micronuclei, univalents and a partial arrest of meiosis at severe stress levels (Namuco and O'Toole, 1986). In water stressed barley, abnormal chromosomal pairing and segregation during meiosis was found, leading to loss of pollen fertility (Skazkin and Zavadskaya, 1957). Cytological studies in Sesbania pea found that waterlogging stress resulted in various chromosomal aberrations and a reduction in pollen fertility (Srivastava and Kumar, 2016). Verde (2003) has also presented evidence that meiotic recombination increases in response to droughting in two genotypes of maize (Zea mays). van Tol et al. (2018) detected a 70\% increase in recombination frequency between markers in response to salt stress of Arabidopsis, and genotyping revealing that $\mathrm{CO}$ fluctuation was not limited to the region between the marker genes but occurred throughout the genome. Modliszewski et al. (2018) did not detect the same effect under similar conditions in the same species. Considering that elevated $\mathrm{CO}_{2}$ levels is one of the most prominent causes of climate change, it is surprising that little research has been conducted to examine its influence 
on meiosis. Koti et al. (2005) showed no effect of elevated $\mathrm{CO}_{2}$ on pollen viability in Glycine max, inferring that meiosis was also unaffected.

\section{AGRICULTURAL INPUTS}

Innovations that emerged during the 'Green Revolution' led to a steady rise in agricultural output across the globe (Tilman et al., 2002). These gains were driven principally by the development of new crop varieties and through the increased use of inputs, namely synthetic fertilizer and pesticides. The benefits of these inputs to crop productivity are clear and well documented, as are the negative impacts on the adjoining environment. Agricultural pollutants can influence natural non-target plant populations in close proximity via direct contact (e.g., spray drift), or may affect a much larger area via groundwater contamination (Moss, 2008).

\section{FERTILIZER}

The global demand for fertilizer nutrients $\left(\mathrm{N}, \mathrm{P}_{2} \mathrm{O}_{5}\right.$, and $\left.\mathrm{K}_{2} \mathrm{O}\right)$ has increased steadily since the 1960s, and is predicted to increase from 184.02 million tons in 2015 to over 200 million tons in 2020 (Food and Agriculture Organization [FAO], 2017). It has long been recognized that nutrient state influences meiotic processes. One of the first studies used a sterile $F_{1}$ hybrid between Gilia millefoliata and G. achilleaefolia, and observed that plants grown in rich loam had consistently higher bivalent frequencies, more chiasmata per bivalent on average, and fewer anaphase bridges than those grown in sand (Grant, 1953). Later, Griffing and Langridge (1963) determined the optimal growth conditions for elevated levels of recombination in tomato, a key component in commercial breeding programs. They observed that the $\mathrm{CO}$ frequency for a known interval decreased from 17 to $6 \%$ over a 6 months period during which no additional fertilizer was supplied. Subsequent addition of fertilizer restored the $\mathrm{CO}$ frequency to $12 \%$, implying that nutrient-rich conditions enhance the rate of CO (Griffing and Langridge, 1963).

Subsequent investigations used a more systematic approach in order to isolate particular components, which had the greatest influence on meiosis. In an early example of such an approach, Law (1963) determined the influence of high and low concentrations of potassium and calcium on chiasma frequency in Lolium temulentum grown at both 20 and $30^{\circ} \mathrm{C}$. High potassium increased chiasma frequency at both temperatures, and reduced its variance in the high temperature regime (Law, 1963). Bennett and Rees (1970) observed subsequently the same phenomena in rye (Secale cereale) grown under high phosphate conditions, recording higher chiasma frequencies and lower variance compared with controls. One of the most detailed studies of the effects of phosphate was conducted in Arabidopsis by comparing the recombination rate between pairs of genes conferring resistance to kanamycin and hygromycin (Barth et al., 2000). Under 10-fold higher levels of phosphate, recombination between loci on chromosomes 1 and 2 was significantly reduced, whilst intervals on chromosomes 4 and 5 showed minor, nonsignificant increases in recombination.
High phosphate also has a notable effect on a desynaptic barley mutant, enhancing the formation of chiasmata to 10.6 per cell compared to 7.7 for the control (Fedak, 1973). In a subsequent study, Dhesi (1975) noted a significant increase in chiasmata at metaphase I in a desynaptic mutant of pearl millet (Pennisetum glaucum) subjected to elevated levels of phosphate or potassium. However, elevated phosphate does not influence recombination in all species, such as soybean (G. max) (Hanson, 1961).

All of the studies described above used diploid plant species. However, Grant (1953) reported that bivalent frequency dramatically increases in a neoallotetraploid formed from the hybridisation between G. millefoliata and G. achilleaefolia when watered with a solution of mineral nutrients. Autotetraploid rye grown in Hoagland's solution II containing nitrogen has a higher quadrivalent frequency, at the expense of bivalent formation, and the same number of chiasmata compared to plants grown without nitrogen (Hossain, 1978). More recently, Hoagland's solution has also been shown the significantly increase $\mathrm{CO}$ formation in wheat and wheat-rye hybrids lacking the $P h 1$ locus, which suppresses COs between homoeologs (Martín et al., 2017). A subsequent study showed that the magnesium in the Hoagland's solution was responsible for the observed phenotype (Rey et al., 2018).

\section{PESTICIDES}

Crop protection agrochemicals are another cornerstone of modern agriculture and are essential for minimizing yield losses. In 2015 alone, a total of 2,752,759 tons of active product was applied to crops globally, predominantly as herbicides, fungicides, and insecticides (Food and Agriculture Organization [FAO], 2018 ${ }^{2}$. The influence of each of these pesticides groups on meiosis has been assessed (Sharma and Panneerselvam, 1990) and key examples are highlighted below.

One of the earliest studies to examine the influence of herbicides on meiosis was conducted by Wuu and Grant (1966). Barley seeds were soaked in 3-(3,4-dichlorophenyl)-1methoxy-1-methylurea for $24 \mathrm{~h}$ prior to sowing, and meiocytes collected from the treated plants were analyzed cytologically. The authors documented numerous defects such as chromatin bridges, micronuclei, and asynchronous division. Sharma et al. (1981) examined the influence of three additional herbicides, bromacil, lenacil, and terbacil, all applied to barley seed at various concentrations for $6 \mathrm{~h}$. Treatment with terbacil significantly reduced the chiasma frequency and was as disruptive as ethyl methanesulfonate (EMS), which was included as a control compound. The susceptibility of meiosis in V. faba to 2, 4, 5-trichlorophenoxyacetic acid (2,4,5-T), 2, 4dichlorophenoxyacetic acid (2,4-D) and 2, 4-dichlorophenol, an intermediate product in the degradation pathway of 2, 4D, was assessed by Amer and Ali (1974). The compounds were applied to both seed and sprayed onto 15 and 35 days old plants. Treatment at 35 days with 2, 4, 5-T led to the highest levels of sterile pollen grains resulting from stickiness, lagging chromosomes, and chromosome fragmentation during meiosis.

\footnotetext{
${ }^{2} \mathrm{http} / / /$ www.fao.org/faostat
} 
Badr et al. (1987) reported terbutryn also induced chromosomal abnormalities in $11.3 \%$ of cells undergoing meiosis in $V$. faba.

Liang et al. (1969) sprayed sorghum (Sorghum vulgare) plants that ranged between 5 and $20 \mathrm{~cm}$ in height with atrazine (2-chloro-4-ethylamino-6-isopropylamino-s-triazine), 2,4-D, alkanolamine salts of 2,4-D, and non-phytotoxic petroleum oil (crop oil), or their combinations. All increased the level of cytological aberrations at meiosis, including inducing aneuploidy and polyploidy. Two further studies assessed the influence of atrazine on meiosis in sorghum. Lee et al. (1974) also found a high degree of meiotic abnormalities in atrazinetreated sorghum, while a subsequent study noted more subtle changes to the meiotic nuclear landscape; additional nucleoli were frequently observed at diplotene and early diakinesis in treated plants (Currie and Liang, 1996). Soriano (1984) also reported the influence of a herbicide, whose active ingredient is $\mathrm{N}$-(butoxymethyl)-2-chloro-2', 6'-diethyl-acetanilide, applied at concentrations of $0.05-0.20 \%$ to sorghum seed. The lowest concentration induces aneuploidy in $2.9 \%$ of metaphase I cells, increasing to $8.8 \%$ at the highest concentration, compared to $0 \%$ in untreated plants. Interchanges, bridges and fragmentation were observed during meiosis I only at the higher concentrations.

The herbicide maleic hydrazine was applied to seed of Helianthus annuus at concentrations of $10^{-5} \mathrm{M}$ to $10^{-2} \mathrm{M}$ to determine its meiotic influence (Kaymak, 2005). This study reports not only a significant increase in abnormalities during both the first and second meiotic divisions, even at the lowest concentration tested, but also identifies a significant degree of abnormalities in the subsequent generation. A more recent study by Singh and Srivastava (2014) tested the effect of glyphosate and pendimethalin applied to the foliage of Vigna mungo 21 days from the point of sowing. They noted numerous defects, including chromatin bridges, laggards at anaphase I, disturbed spindle formation and binucleate cells in $17 \%$ and $21 \%$ of pollen mother cells (PMCs) treated with pendimethalin and glyphosate, respectively.

The influence on meiosis of a wide range of insecticides has been assayed in V. faba (Amer and Farah, 1968, 1976, 1980, 1983; Amer and Ali, 1983). In one of the earliest studies, Amer and Farah (1968) applied N-methyl-1-naphthylcarbamate over various timeframes. After a single application, $8.7 \%$ of PMCs contained an aberration at diakinesis and metaphase I, compared to $1 \%$ in the control, rising to $23 \%$ if applied daily over a 7-day period. Defects were also later observed at anaphase I, metaphase II, and anaphase II (Amer and Farah, 1968). In V. faba both O,O-dimethyl- $N$-methylcarbamidomethyl dithiophosphate and $O$-isopropyl- $N$-phenyl carbamate applied to seed prior to planting or sprayed (on day 15 or 35) induced multipolar anaphase II, along with a host of other types of meiotic abnormalities, the effects of which did not influence the yield phenotype of the successive two generations (Amer and Farah, 1976). One of the most profound effects was noted for the organophosphate insecticide chlorpyrifos (0,0-diethyl 0-3, 5, 6-trichloro-2-pyridyl phosphorothioate). When applied as a spray to seedlings or at the flowering stage the result was the same; chromosome stickiness was observed in more than $80 \%$ of the abnormal meiocytes
(Amer and Farah, 1983). A single application during flowering of another organophosphate, methamidophos (0,S-dimethyl phosphoramidothioate), was sufficient to significantly increase the number of abnormal PMCs to $8.4 \%$, compared to $1 \%$ in the control (Amer and Farah, 1987). Repeat application exacerbates the effect, causing abnormalities in $21 \%$ of PMCs.

The meiotic influence of four organophosphorus insecticides applied to Capsicum annuum was assessed by Devadas et al. (1986). The insecticides, namely dimethoate, DDVP, phosphomidon and monocrotophos were applied to seed at concentrations of $0.1,0.5$, and $1.0 \%$ for $24 \mathrm{~h}$. Each treatment depressed pollen viability, with the degree of sterility rising with increasing concentration. The sterility is caused by univalents, multivalents, bridges, lagging chromosomes, nonsynchronization, multipolar formation, micronuclei, unoriented and unequal disjunction of chromosomes identified in the preceding meiosis. The authors also claim that the insecticides tested are as disruptive as ionizing radiation. Reddy and Rao (1981), also working with C. annuum, focused on two different compounds, $\mathrm{BHC}$ and Nuvacron, the latter being a organophosphorus systemic and contact insecticide. The compounds were applied at a range of concentrations to both the seed and sprayed on plants at fortnightly intervals. Both were found to induce abnormalities during meiosis, ranging from 3.1 to $5.6 \%$ for BHC and $7.7-15.6 \%$ for Nuvacron. The authors note that the lowest concentration is favored by Indian farmers at the time of publication. A later study by Lakshmi et al. (1988) examined the influence of Ekalux EC 25 [0-diethyl-o-(quinoxylinyl-2) phosphorothionate] and Metasystox (oxydemeton-methyl = S-(2(ethyl-sulphinyl)-ethyl) \& 0,0-dimethyl phosphorothioate), applied to seed of C. annuum followed by four spray applications during growth. This study is one of few to score chiasma frequency, and noted a steady decline in COs with increasing concentration of each insecticide. COs were reduced to the lowest number of 21.08 for Ekalux EC 25 and 20.5 for Metasystox, compared to 23 in the control. Other meiotic defects including laggards, bridges, stickiness and univalents were also noted in this study.

Kuchy et al. (2016) examined the effects on A. cepa of an organophosphate insecticide containing dichlorvos (2,2dichlorovinyl dimethyl phosphate) and a organochlorine insecticide, endosulfan. The organophosphate compound was the most potent at inducing abnormalities, affecting $11-27 \%$ of PMCs depending upon which concentration was applied, compared to $3 \%$ in the control. Endosulfan also caused numerous meiotic failures, with 9-20\% PMCs containing defects, depending upon the concentration used. The most common abnormality observed was stickiness at metaphase I and II.

One of the earliest investigations of the influence of fungicides on meiotic recombination was conducted by Bennett (1971) who tested Ethirimal (5-butyl-2-ethylamino-4-hydroxy-6-methyl pyrimidine), a systemic compound applied as a seed dressing in barley. The mean chiasma frequency in each of three cultivars was significantly reduced to $2-4 \%$ lower than the control. A later study in the same species showed that the systemic fungicides fuberidazole, carboxin, and oxycarboxin (but not thiabendazole) all significantly reduced chiasma frequency (Sharma et al., 1983). 
Carboxin and oxycarboxin has an effect even at the lowest concentration tested.

The transgenerational effect of the fungicide carbendazim (2-methoxy-carbamoyl benzimidazole), was studied in two different cultivars of Pisum sativum (Choudhary and Sajid, 1986). Plants were sprayed four times during development with the recommended dose of $0.2 \%$ aqueous solution, and at $0.4 \%$. Both concentrations significantly altered the chiasma frequency, with one cultivar being more susceptible, implying a genotypic interaction with the fungicide. The subsequent two generations of the treated plants, which received no further applications of fungicide, also had a significantly altered CO landscape, one cultivar having fewer COs contrasting with the second which had more. Abnormalities such as stickiness, fragmentation and micronuclei, were also observed in PMCs of $A$. cepa treated with either one of four different Dithane based fungicides or treated with carbendazim (methyl-2-benzimidazole carbamateMBC) (Mann, 1977; Kuchy et al., 2016). Fisun and Rasgele (2009) treated $A$. cepa bulbs with roots $1.5-2 \mathrm{~cm}$ in length with different concentrations (1800-6000 ppm) of the fungicide tebuconazole, for 3-24 h. All treatments resulted in a significant increase in meiotic abnormalities, including a significant increase in the number of quadrivalents, believed to be a result of chromosome translocations.

\section{OTHER ANTHROPOGENIC INFLUENCES}

Whilst environmental stresses and agricultural pollutants commonly affect meiosis in plants, there are also a number of other anthropogenic factors that can have a similar effect. As the human population increases and encroaches upon the global natural environment, the trail of anthropogenic influences grows commensurately. Increasing agricultural and industrial developments expose plant populations to new and different chemical and physical agents and places them in environments that can potentially alter their development. There is greater pollution from industrial and automotive combustion, commercially and pharmaceutically used solvents, additives, chemicals and an increase in pathogen prevalence worldwide (Evans et al., 2008; Gaffney and Marley, 2009; Tornero and Hanke, 2016).

\section{HEAVY METALS AND COMBUSTED GASSES}

Heavy metal contamination of the environment is increasing due to human activity, with many sources of pollution primarily entering water courses and polluting the land. The accumulation of heavy metals and metalloids in soil also originate from other sources, such as emissions from industrial areas, leaded fuels and paints, sewage sludge, biosolids, animal manures, spillage of petrochemicals and combustion residues (Khan et al., 2008; Zhang et al., 2010).

Samples of agricultural soils from the siling reservoir watershed in Zhejiang Province and an area of north east China that has been of intensively farmed for decades were found to contain high levels of cadmium contamination (Naveedullah et al., 2013; Shan et al., 2013). At some metalliferous sites there can be 100 times elevated metal concentrations in the soil compared with uncontaminated areas (Bert et al., 2002). Soil samples from agricultural areas of Jiaxing, a rapidly industrializing area in the Yangtze Delta of China, has localized hot spots of pollution of copper, zinc, lead, chromium, nickel and cadmium (Xu et al., 2014). The concentrations of the heavy metals lead, copper, cadmium, and zinc can be further increased by urban runoff or combustion sources, and copper, chromium and tin levels even further increased by automobile break and tire wear (Davis et al., 2001; Hulskotte et al., 2007; Shan et al., 2013). Another surprising pollution source are shooting ranges as the soil there often has higher levels of antimony, nickel, lead, copper and zinc and can be used for animal grazing when not in use or decommissioned (Robinson et al., 2008; Bannon et al., 2009).

There may be no cause for concern for some current levels of heavy metal contamination of the soil, and potentially the food chain, as they may often be below the acceptable thresholds for safe human consumption. There is, however, reason to investigate what effects they may have on the recombination landscape of the plants and crops that grow in these areas, as heavy metals are known to effect plant development in a number of ways. Arabidopsis plants treated with 50 or $100 \mathrm{mM}$ copper, cadmium or nickel have at least a twofold increase in somatic homologous recombination frequency with successive treated generations exhibiting even higher increases (Rahavi et al., 2011). This study also found that the subsequent generation, which was not exposed to any stress, still possessed significantly higher residual rates of recombination when compared to the non-exposed progeny. Further studies found that chromosomal abnormalities, including chromosomal bridges, scattering and precocious movements occurred in G. max and Z. mays when treated with cadmium (Kumar, 2007; Kumar and Rai, 2010). Similar results were found when $H$. vulgare was treated with a combination of cadmium and chromium. This combination treatment also resulted in a significant decrease in the number of pollen grains per anther and a significant increase in pollen sterility (Mittal and Srivastava, 2014).

Although the current known levels of heavy metals found in soils due to anthropogenic influences may not be enough to modify the recombination landscape alone, there are other agents, such as anthropogenic gasses, that are known to have detrimental effects on plants. A cytogenetic test based upon quantifying micronuclei resulting from chromosome breakage in meiotic pollen mother cells T. paludosa (Trad-MCN) has found that various anthropogenic gasses such as $\mathrm{NO}_{2}, \mathrm{SO}_{2}, \mathrm{O}_{3}$, $\mathrm{HN}_{3}$, and EMS have clastogenic effects. Both gaseous $\mathrm{HN}_{3}$, and EMS were clastogenic after $6 \mathrm{~h}$ exposures while $\mathrm{SO}_{2}$ and $\mathrm{NO}_{2}$ required 22 and 24 h, respectively (Ma et al., 1982; Rodrigues et al., 1996). Several indoor environments containing pipe and tobacco smoke, and formaldehyde fumes were found by the Trad-MCN assay to cause chromosomal breakage, as well as several outdoor locations such as parking garages, truck and bus stops, agrochemical industrial sites, a P-dichlorobenzene treated 
herbarium and an industrial site (Ma et al., 1980, 1982; Ma and Harris, 1987a,b). Although this only shows that T. paludosa can be clastogenically affected by anthropogenic environments, it emphasizes the unintended consequences of human activities.

Heavy metals and combusted gasses in the environment are not the only anthropogenic sources that could change the recombination landscape of crops around the world; there are also large amounts of pharmaceutical chemicals that pass into the environment and to the soil.

\section{PHARMACEUTICAL CHEMICALS}

As pharmaceutical drug use increases worldwide, there is growing concern for the high level of pharmaceutical residues in aquatic environments (Uslu et al., 2013). Treatment plants are not always able to remove pharmaceutical residues from sewage completely and often release amounts into the receiving waters (Heberer, 2002; Gaw et al., 2014; Küster and Adler, 2014; Zhang et al., 2016). While a large part of the concern comes from the potential of these residues to affect aquatic life and enter the drinking water supply, there is justification to question the effects they could have on plant life when treated biosolids are applied to agricultural land.

Extremely low levels of the anti-cancer drug bleomycin, known to cause an increase in DSBs and increased somatic recombination, have been found at concentrations of 11 $19 \mathrm{ng} / \mathrm{L}$ and $<5-17 \mathrm{ng} / \mathrm{L}$ in sewage treatment effluent and rivers, respectively (Aherne et al., 1990). Whilst these doses are well below the normal chemotherapeutic doses administered (20$30 \mathrm{mg} / \mathrm{m}^{-2}$ ), data are sparse concerning the bioaccumulation of bleomycin or the amount that it is used worldwide. Qi et al. (2014) showed that 98 tons of pesticides, 152 tons of pharmaceuticals, 369 tons of polycyclic aromatic hydrocarbons and 273 tons of household and industrial chemicals are flushed annually into the East China Sea by the Yangtze river. This level of pollution could potentially affect meiotic recombination in plants, but virtually no investigations have been undertaken. The recent significant increase in drug-resistant bacterial strains is often attributed to the indiscriminate use of antibiotics by today's society. However, there should perhaps also be concern about the bioactivity of waste antibiotics in the environment. Some antibiotics in water courses and agricultural land are known to affect plants. For example, ciprofloxacin has been found in municipal waste water (Lee et al., 2007) and in soil samples (Golet et al., 2002; Goulas et al., 2016) and is known to cause double strand DNA breaks in Arabidopsis, (Rowan et al., 2010). Ciprofloxacin's bactericidal action comes from the inhibition of topoisomerase II (DNA gyrase) and topoisomerase IV, required for various bacterial DNA processes including replication, transcription, repair, strand supercoiling repair, and recombination (Aldred et al., 2014), and a recent study found that ciprofloxacin targets $A$. thaliana gyrase (EvansRoberts et al., 2016). Tetracycline has been shown to induce meiotic aberrations including stickiness, laggards, bridges, and fragments in A. cepa (Mann, 1978), and has been found in soil fertilized with liquid manure and in soil and water near intensive commercial livestock operations (Hamscher et al., 2002; Thiele-Bruhn, 2003).

The increase in anthropogenic chemicals in the environment is not limited to pharmaceuticals, but also applies to chemicals resulting from human consumption. Caffeine can be found in soil due to the reuse of treated wastewater for irrigation (Bruton et al., 2010; Williams and McLain, 2012). Anis and Wani (1997) found that caffeine-treated populations of Trigonella foenum-graecum exhibited several meiotic abnormalities including laggards, univalents, bridges, stickiness, and precocious chromosome movements. A $0.1 \%$ caffeine solution was administered to $S$. cereale and abnormalities such as laggards, bridges and fragments and decreased chiasma frequency were observed (de la Peña et al., 1981). The widely used chemical bisphenol A (BPA) affects microtubule arrays of meristematic root-tip cells of $P$. sativum resulting in the stalling of cytokinesis, deranged interphase and mitotic microtubule arrays, and abnormal chromosome segregation (Adamakis et al., 2013).

\section{PATHOGENS}

The full impact climate change will have on the prevalence and spread of virus disease epidemics in natural vegetation and cultivated plants and crops is still unknown. Research suggests that elevated environmental $\mathrm{CO}_{2}$ levels can alter hormone production in plants and precipitate the observed shift in susceptibility to insect herbivores and pathogens (Casteel et al., 2012; Zhang et al., 2015). Whilst research to understand the possible effects of some common climate change scenarios is ongoing, reviewed extensively in Jones (2016) and Trebicki et al. (2017), we still do not know what impact climate change may have on the recombination landscape of plants. Climatic changes are compounding the threat of spread of plant pest and diseases. A recent analysis indicated that crop pests are moving $2.7 \mathrm{~km}$ poleward annually and that on average, $10 \%$ of the major plant pests and disease agents have already infested half of the countries that they potentially could infect (Bebber et al., 2013, 2014). Carica papaya infected with papaya ring spot virus exhibited an increase in laggard chromosomes, and had a lower mitotic index and worse pollen viability compared to its healthy counterpart (Kumar Ravindra, 2017). Infection of Arabidopsis with the oomycete pathogen Peronospora parasitica has been shown to lead to an increase in somatic recombination frequency (Lucht et al., 2002). Interestingly, when Molinier et al. (2006) treated Arabidopsis with flagellin, an elicitor of plant defenses, they found that not only did somatic homologous recombination increase in the treated individual but also in successive generations. Nicotiana tabacum treated with the tobacco mosaic virus behaves in a similar way; somatic recombination increased in both the subject and its offspring, with one study showing that the offspring even exhibited a delay in symptom development when infected with viruses (Kovalchuk et al., 2003; Kathiria et al., 2010). Si et al. (2015) found that in some of the $F_{2}$ generation of O. sativa treated with rice blasts spores there was a significantly higher number of CO events compared to the controls. Datura quercifolia treated with mosaic virus resulted in a drastic decrease 
in chiasma frequency, and the presence of univalents led to many irregularities such as laggards, micronuclei and a significant reduction in pollen and seed fertility (Kaul, 1968). Caldwell (1952) noted that Solanum lycopersicum treated with mosaic virus led to the breakdown of meiosis and in some instances cells forming with an irregular number of chromosomes. Yao et al. (2013) found that a local infection of either tobacco mosaic virus or oilseed rape mosaic virus leads to a systematic increase in somatic homologous recombination frequency, with older plants having a higher recombination frequency than younger plants. Lycopersicon esculentum and $H$. vulgare infected with barley stripe mosaic virus exhibited an increase in various chromosome abnormalities and a shift in chiasmata toward the interstitial regions (Andronic, 2012). Anthropogenic influences resulting in a changing climate can lead to an increased level of viral vectors and more disease epidemics in plants worldwide, but they could also be enough to change the meiotic recombination landscape forever.

\section{LIMITATIONS OF CURRENT STUDIES}

As outlined above, there is a wide range of anthropogenic factors that have been shown to cause various meiotic abnormalities. In the vast majority of cases, the precise biochemical action induced by the treatment during meiosis has not been ascertained; temperature is the notable exception (see earlier section for detail). Many studies reported abnormal meiocytes with chromosome stickiness, bridges, fragmentation and micronuclei. However, it is yet to be determined if the factors themselves are clastogenic and cause DNA damage directly, or whether they interfere with the repair of double strand breaks (DSBs) formed naturally during prophase I. Cytology of fixed meiotic material was by far the most prevalent method of determining the extent of meiotic abnormalities induced by each treatment, and in most studies only gross changes were recorded. More subtle influences, such as changes in chiasma frequency at metaphase I, were recorded in only approximately a third of the studies summarized in Table 1. The scoring of chiasmata is not sensitive and cannot detect small changes in recombination frequency, making it likely that more subtle effects at the lower concentration range were not detectable.

The biochemical pathways affected by these treatments may be elucidated by studies in non-plant species. Allard and Colaiacovo (2010) used Caenorhabditis elegans to analyze the meiotic molecular pathways affected by BPA. They showed that BPA perturbs both synaptonemal complex and chromosome integrity during pachytene, and also alters DSB repair progression and activation of the DNA damage checkpoint. The effect of the herbicide atrazine on meiosis has been studied in both male and female mice (Gely-Pernot et al., 2015, 2017). In male mice, atrazine reduced sperm count by $68 \%$, caused by a delay in meiotic progression arising from the persistence of unrepaired DSBs (Gely-Pernot et al., 2015). The study also found that the herbicide affects the expression of genes involved in mitochondrial function, steroid-hormone function and GTPase activity, and also altered the pattern of histone $\mathrm{H} 3$ trimethylation at lysine 4 ( $\mathrm{H} 3 \mathrm{~K} 4 \mathrm{me} 3)$. A subsequent study switched focus to female meiosis and found that atrazine increased the level of oxidative stress in the nuclei of meiotic cells, as measured by the level of 8-oxo-guanine, which affected DBS repair, synapsis and CO frequency (Gely-Pernot et al., 2017).

Another shortcoming of most published studies is that the concentrations of the chemical treatments used cannot be related to those used in agriculture or experienced by plants in natural environments. The biological significance, in terms of potential threat to the meiotic process, is therefore difficult to ascertain. Taking agricultural inputs as an example, a number of agrochemicals have been subsequently banned or their application drastically reduced. The persistence of these substances in the environment also varies, and may have the potential to affect plant communities long after their last application. For example, atrazine was first introduced as a herbicide in 1958 but was subsequently withdrawn from use in most Northern European countries in the early 1990s, and banned from the whole European Union in 2004. Traces of atrazine are still detectable in soil sampled from agricultural land in Germany where the last application was prior to 1991, and in marine sediments of the Mediterranean (Noedler et al., 2013; Vonberg et al., 2014).

In the majority of studies cited, only one treatment was applied to a single plant species that was grown under controlled conditions. This is starkly different to reality where multiple xenobiotics, abiotic and biotic stresses may impact together in one environment. To date, only one published study examines the impact on meiosis of plant species growing in polluted environments. Zohair et al. (2012) sampled 14 species belonging to the Cyperaceae and Poaceae growing in the vicinity of industrial sites and agricultural fields around Karachi, Pakistan, and compared them with their counterparts in unpolluted environments. All of the plant species collected from the contaminated sites had significantly higher numbers of aberrant PMCs with precocious movement, stickiness, aberrant spindles or lagging chromosomes. The prevalence of abnormal PMCs varied greatly between species; the largest effect was observed in Cyperus arenarius where 99\% of PMCs contained defects, compared to $13 \%$ for the control, contrasting with Ochtochloa compressa where only 7\% of PMCs were defective, compared to $2 \%$ in the control. The study also identified an elevated number of unreduced dyads and sterile pollen grains.

Numerous genetic modifiers of recombination have been identified. One of the first studies to note this was Gale and Rees (1970) who observed small but significant differences in chiasma frequencies in five Hordeum species, attributed to genotypic variation in the populations. Ziolkowski et al. (2017) identified that $56.9 \%$ of $\mathrm{CO}$ variation in a $\mathrm{F}_{2}$ population from a cross between two Arabidopsis accessions, Columbia and Landsberg, was caused by semi-dominant polymorphisms in HEI10, a conserved ubiquitin E3 ligase. Interaction between such genetic elements and environmental variables has not been extensively studied. Rezaei et al. (2010) noted an interaction between the extent of meiotic irregularities and environmental conditions in Tritium turgidum. Zheng et al. (2014) reported that 
cyclin-dependent kinase G1 (CDKG1) was required for normal levels of synapsis and $\mathrm{CO}$ formation in male meiosis in Arabidopsis, but only at elevated temperatures.

The range of plant species assessed for their meiotic sensitivity to anthropogenic factors is very narrow and confined to angiosperms, and in most instances only those used in agriculture. Single species are usually examined as targets for agrochemicals, and most non-target species are ignored. The effects on angiosperms in non-agricultural habitats, such as woodlands or estuaries and other plant groups, such as gymnosperms, are less known because of the difficulties of experimenting with such species. One such study by Bykova et al. (2018) found that a $27 \%$ reduction in precipitation resulted in a $35 \%$ reduction in viable pollen grains compared to the control in male Quercus ilex. Most of the studies relate to male meiosis, so the sensitivity of the ovule is largely unknown. Hundreds of xenobiotic compounds have been assessed, including those tested by the Tradescantia Trad-MCN assay, but this represents a small fraction of the 10,000s of compounds present in the environment (Donner et al., 2010; European Psychiatric Association [EPA], 2018).

\section{EVOLUTIONARY CONSEQUENCES}

Empirical research has shown that both the number and distribution of recombination events are tightly controlled, and such non-random patterns have been shown to be stable through generations (see review by Stapley et al., 2017). In all plant species, there are regions of the genome that have few COs events; such regions are termed cold spots. The result of such linkage-disequilibrium is to maintain supergene groups, coevolved loci or favorable linkage groups, which are of benefit to the plant. Alternatively, undesirable allele combinations could be maintained. As previously discussed, elevated temperature modulates the meiotic landscape of barley and Arabidopsis and disrupts linkage groups (Phillips et al., 2015; Lloyd et al., 2018; Modliszewski et al., 2018), which could alter the evolutionary fitness of the plants subjected to this stress.

Many of the anthropogenic stresses, including temperature, agrochemicals and fungicides were reported to cause spindle aberrations during the first and second meiotic division that in some instances gave rise to unreduced gametes and the potential for polyploidisation (Mason and Pires, 2015). High nutrient conditions aids the stabilization of neopolyploid and could drive the evolution of new polyploidy species. Xenobiotic compounds currently found in the environment have no equivalent in the history of our planet and therefore the long-term effect in terms of promoting polyploidy are unknown. The environmental climate of the planet has fluctuated on numerous occasions, and its impact on ploidy recognized. One such event occurred at

\section{REFERENCES}

Adamakis, I. D., Panteris, E., Cherianidou, A., and Eleftheriou, E. P. (2013). Effects of bisphenol A on the microtubule arrays in root meristematic cells of Pisum sativum. Mutat. Res. 750, 111-120. doi: 10.1016/j.mrgentox.2012.10.012 the Cretaceous-Tertiary (KT) boundary that caused the mass extinction of many species, including about $60 \%$ of plant species, but drove the formation of polyploid species (Fawcett et al., 2009; Vanneste et al., 2014). Polyploidisation is believed to confer better adaptability and tolerance to altered environmental conditions, a trend that may be repeated in the current climate change cycle.

Plant speciation is often associated with structural changes in the genome resulting from aneuploidy, dysploidy, or other chromosome rearrangements such as translocations, inversions, fusions, or fissions (De Storme and Mason, 2014). None of the studies cited in this review report such structural changes, but none specifically set out to identify such morphological changes. Notable abnormal chromosome conformations, such as laggards, bridges, fragments, micronuclei, and aneuploidy are reported in many of the studies, and are capable of altering the genomic landscape of the subsequent generation.

\section{SUMMARY}

The influence of the human race on the natural environment is undeniable, ranging from altering climatic conditions globally to the local contamination with a specific xenobiotic compound. The influence of many such factors have been reported in a number of different angiosperms, with effects ranging from altered patterns of recombination to severe chromosome damage originating from stickiness and bridges. In most cases, only basic cytology has been used which has shed little light on the underlying mode of action of the factors. Many of the citations predate the development of the sensitive assays now available, and it would be profitable to use such methods to identify how these factors impinge upon on the biochemical pathways operating during meiosis, using concentrations of xenobiotics of relevance to plant populations. The long-term consequences of destabilizing the genome may have a profound evolutionary legacy.

\section{AUTHOR CONTRIBUTIONS}

All authors listed have made a substantial, direct and intellectual contribution to the work, and approved it for publication.

\section{FUNDING}

DP was supported through a United Kingdom Biotechnology and Biological Sciences Research Council (BBSRC) Strategic Programme Grant (BBS/E/W/0012843D). LF was supported by a studentship from the Institute of Biological, Environmental and Rural Sciences, Aberystwyth University.

Aherne, G. W., Hardcastle, A., and Nield, A. H. (1990). Cytotoxic drugs and the aquatic environment: estimation of bleomycin in river and water samples. J. Pharm. Pharmacol. 42, 741-742. doi: 10.1111/j.2042-7158.1990.tb06574.x

Aldred, K. J., Kerns, R. J., and Osheroff, N. (2014). Mechanism of quinolone action and resistance. Biochemistry 53, 1565-1574. doi: 10.1021/bi5000564 
Allard, P., and Colaiacovo, M. P. (2010). Bisphenol A impairs the double-strand break repair machinery in the germline and causes chromosome abnormalities. Proc. Natl. Acad. Sci. U.S.A. 2, 20405-20410. doi: 10.1073/pnas.1010386107

Amer, S., and Ali, E. (1983). Cytological effects of pesticides XIV. Effects of the insecticide Difterex “Trichlorophon" V. faba plant. Cytologia 48, 761-770. doi: 10.1508/cytologia.48.761

Amer, S. M., and Ali, E. M. (1968). Cytological effects of pesticides: II. Meiotic effects of some phenols. Cytologia 33, 21-33. doi: 10.1508/cytologia.33.21

Amer, S. M., and Ali, E. M. (1974). Cytological effects of pesticides V. Effects of some herbicides on Vicia faba. Cytologia 39, 633-643. doi: 10.1508/cytologia. 39.633

Amer, S. M., and Farah, O. R. (1968). Cytological effects of pesticides III. Meiotic effects of N-methyl-1-naphthyl carbamate "Sevin". Cytologia 33, 337-344. doi: 10.1508/cytologia.33.337

Amer, S. M., and Farah, O. R. (1976). Cytological effects of pesticides. VIII. Effects of the carbamate pesticides "IPC", "Rogor", and "Duphar" on Vicia faba. Cytologia 41, 597-606. doi: 10.1508/cytologia.41.597

Amer, S. M., and Farah, O. R. (1980). Cytological effects of pesticides X. Meiotic effects of "Phosvel". Cytologia 45, 241-245. doi: 10.1508/cytologia.45.241

Amer, S. M., and Farah, O. R. (1983). Cytological effects of pesticides XIII. Meiotic effects of the insecticide "Dursban". Cytologia 48, 557-563. doi: $10.1508 /$ cytologia.48.557

Amer, S. M., and Farah, O. R. (1987). Cytological effect of pesticides VIII Meiotic effects of the insecticide Methamidophos. Cytologia 52, 303-307. doi: 10.1508/ cytologia.52.303

Andronic, L. (2012). Viruses as triggers of DNA rearrangements in host plants. Can. J. Plant Sci. 92, 1083-1091. doi: 10.4141/cjps2011-197

Anis, M., and Wani, A. A. (1997). Caffeine induced morpho-cytological variability in fenugreek, Trigonella foenum-graecum. Cytologia 62, 343-349. doi: 10.1508/ cytologia.62.4_343

Aslam, R., Bhat, T. M., Choudhary, S., and Ansari, M. Y. K. (2017). An overview on genotoxicity of heavy metal in a spice crop (Capsicum annuum L.) in respect to cyto-morphological behaviour. Caryologia 70, 42-47. doi: 10.1080/00087114. 2016.1258884

Badr, A., Hamoud, M., and Haroun, S. (1987). Effect of the herbicide terbutryn on meiosis, yield and mitotic chromosomes in C 2 plants of Vicia faba L. Biol. Plant. 29, 70-72. doi: 10.1007/BF02902322

Bannon, D. I., Drexler, J. W., Fent, G. M., Casteel, S. W., Hunter, P. J., Brattin, W. J., et al. (2009). Evaluation of small arms range soils for metal contamination and lead bioavailability. Environ. Sci. Technol. 43, 9071-9076. doi: 10.1021/ es901834h

Barth, S., Melchinger, A. E., Devezi-Savula, B., and Lubberstedt, T. (2000). A highthroughput system for genome-wide measurement of genetic recombination in Arabidopsis thaliana based on transgenic markers. Funct. Integr. Genomics 1, 200-206. doi: 10.1007/s101420000030

Bebber, D. P., Holmes, T., and Gurr Sarah, J. (2014). The global spread of crop pests and pathogens. Global Ecol. Biogeogr. 23, 1398-1407. doi: 10.1111/geb.12214

Bebber, D. P., Ramotowski, M. A. T., and Gurr, S. J. (2013). Crop pests and pathogens move polewards in a warming world. Nat. Clim. Change 3, 985-988. doi: $10.1038 /$ nclimate 1990

Bennett, M. (1971). Effects of ethirimol on cytological characters in barley. Nature 230:406. doi: 10.1038/230406a0

Bennett, M. D., and Rees, H. (1970). Induced variation in chiasma frequency in rye in response to phosphate treatments. Genet. Res. 16, 325-331. doi: 10.1017/ S0016672300002585

Bert, V., Bonnin, I., Saumitou-Laprade, P., De Laguérie, P., and Petit, D. (2002). Do Arabidopsis halleri from nonmetallicolous populations accumulate zinc and cadmium more effectively than those from metallicolous populations? New Phytol. 155, 47-57. doi: 10.1046/j.1469-8137.2002.00432.x

Bomblies, K., Higgins, J. D., and Yant, L. (2015). Meiosis evolves: adaptation to external and internal environments. New Phytol. 208, 306-323. doi: 10.1111/ nph.13499

Boyko, A., Hudson, D., Bhomkar, P., Kathiria, P., and Kovalchuk, I. (2006). Increase of homologous recombination frequency in vascular tissue of Arabidopsis plants exposed to salt stress. Plant Cell. Physiol. 47, 736-742. doi: $10.1093 / \mathrm{pcp} / \mathrm{pcj} 045$

Bruton, T., Alboloushi, A., de la Garza, B., Kim, B.-O., and Halden, R. U. (2010). "Fate of caffeine in the environment and ecotoxicological considerations," in
Proceedings of the Contaminants of Emerging Concern in the Environment: Ecological and Human Health Considerations (Washington, DC: American Chemical Society), 257.

Bykova, O., Limousin, J. M., Ourcival, J. M., and Chuine, I. (2018). Water deficit disrupts male gametophyte development in Quercus ilex. Plant Biol. 20, 450-455. doi: 10.1111/plb.12692

Caldwell, J. (1952). Some effects of a plant virus on nuclear division. Ann. Appl. Biol. 39, 98-102. doi: 10.1111/j.1744-7348.1952.tb01001.x

Cardinale, B., Duffy, J., Gonzalez, A., Hooper, D., Perrings, C., Venail, P., et al. (2012). Biodiversity loss and its impact on humanity. Nature 486, 59-67. doi: $10.1038 /$ nature 11148

Casteel, C. L., Segal, L. M., Niziolek, O. K., Berenbaum, M. R., and DeLucia, E. H. (2012). Elevated carbon dioxide increases salicylic acid in Glycine max. Environ. Entomol. 41, 1435-1442. doi: 10.1603/EN12196

Choudhary, S., and Sajid, S. (1986). The behaviour of meiotic chromosomes as revealed through the use of Bavistin on pea. Cytologia 51, 279-288. doi: 10.1508/ cytologia.51.279

Currie, R. S., and Liang, G. H. (1996). Cytological and morphological effects of atrazine and propazine application on grain sorghum. Cytologia 61, 359-363. doi: 10.1508/cytologia.61.359

Davis, A. P., Shokouhian, M., and Ni, S. (2001). Loading estimates of lead, copper, cadmium, and zinc in urban runoff from specific sources. Chemosphere 44, 997-1009. doi: 10.1016/S0045-6535(00)00561-0

de la Peña, A., Puertas, M. J., and Merino, F. (1981). Bimeiosis induced by caffeine. Chromosoma 83, 241-248. doi: 10.1007/BF00286792

De Storme, N., and Geelen, D. (2014). The impact of environmental stress on male reproductive development in plants: biological processes and molecular mechanisms. Plant Cell Environ. 37, 1-18. doi: 10.1111/pce.12142

De Storme, N., and Mason, A. (2014). Plant speciation through chromosome instability and ploidy change: cellular mechanisms, molecular factors and evolutionary relevance. Curr. Plant Biol. 1, 10-33. doi: 10.1016/j.cpb.2014. 09.002

Deniz, B., and Tufan, A. (1998). The influence of phosphate treatment on chromosome segregations and tetrad regularity and using tetrads in determination of regular meiosis diploid. Turk. J. Agric. For. 22, 381-390.

Devadas, N., Rajam, M. V., and Subhash, K. (1986). Comparative mutagenicity of four organophosphorus insecticides in meiotic system of red pepper. Cytologia 51, 645-653. doi: 10.1508/cytologia.51.645

Dhesi, J. (1975). Effect of minerals on the chiasma frequency in desynaptic pearl millet. Curr. Sci. 44, 862-863.

Donner, E., Eriksson, E., Holten-Luetzhoft, H.-C., Scholes, L., Revitt, M., and Ledin, A. (2010). "Identifying and classifying the sources and uses of xenobiotics in urban environments," in Xenobiotics in the Urban Water Cycle: Mass Flows, Environmental Processes, Mitigation and Treatment Strategies, eds D. Fatta-Kassinos, K. Bester, and K. Kümmerer (Dordrecht: Springer), 27-50. doi: 10.1007/978-90-481-3509-7_2

Dowrick, G. J. (1957). The influence of temperature on meiosis. Heredity 11, 37-49. doi: 10.1038/hdy.1957.4

Elliott, C. G. (1955). The effect of temperature on chiasma frequency. Heredity 9 , 385-398. doi: 10.1038/hdy.1955.39

Evans, N., Baierl, A., Semenov, M. A., Gladders, P., and Fitt, B. D. L. (2008). Range and severity of a plant disease increased by global warming. J. R. Soc. Interface 5, 525-531. doi: 10.1098/rsif.2007.1136

Evans-Roberts, K. M., Mitchenall, L. A., Wall, M. K., Leroux, J., Mylne, J. S., and Maxwell, A. (2016). DNA Gyrase is the target for the quinolone drug ciprofloxacin in Arabidopsis thaliana. J. Biol. Chem. 291, 3136-3144. doi: 10.1074/jbc.M115.689554

Fawcett, J. A., Maere, S., and Van de Peer, Y. (2009). Plants with double genomes might have had a better chance to survive the Cretaceous-Tertiary extinction event. Proc. Natl. Acad. Sci. U.S.A. 106, 5737-5742. doi: 10.1073/ pnas.0900906106

Fedak, G. (1973). Increased chiasma frequency in desynaptic barley in response to phosphate treatments. Can. J. Genet. Cytol. 15, 647-649. doi: 10.1139/g73-076

Fisun, K., and Rasgele, P. G. (2009). Genotoxic effects of raxil on root tips and anthers of Allium cepa L. Caryologia 62, 1-9. doi: 10.1080/00087114.2004. 10589659

Food and Agriculture Organization [FAO] (2017). World Fertilizer Trends and Outlook to 2020. Available at: http://www.fao.org/publications 
Francis, K. E., Lam, S. Y., Harrison, B., Bey, A. L., Berchowitz, L. E., and Copenhaver, G. P. (2007). Pollen tetrad-based visual assay for meiotic recombination in Arabidopsis. Proc. Natl. Acad. Sci. U.S.A. 104, 3913-3918. doi: 10.1073/pnas.0608936104

Gaffney, J. S., and Marley, N. A. (2009). The impacts of combustion emissions on air quality and climate - From coal to biofuels and beyond. Atmos. Environ. 43, 23-36. doi: 10.1016/j.atmosenv.2008.09.016

Gale, M. D., and Rees, H. (1970). Genes controlling chiasma frequency in Hordeum. Heredity 25, 393-410. doi: 10.1038/hdy.1970.40

Gaw, S., Thomas, K. V., and Hutchinson, T. H. (2014). Sources, impacts and trends of pharmaceuticals in the marine and coastal environment. Philos. Trans. R. Soc. B 369:20130572. doi: 10.1098/rstb.2013.0572

Gely-Pernot, A., Hao, C., Becker, E., Stuparevic, I., Kervarrec, C., Chalmel, F., et al. (2015). The epigenetic processes of meiosis in male mice are broadly affected by the widely used herbicide atrazine. BMC Genomics 16:885. doi: 10.1186/s12864015-2095-y

Gely-Pernot, A., Saci, S., Kernanec, P.-Y., Hao, C., Giton, F., Kervarrec, C., et al. (2017). Embryonic exposure to the widely-used herbicide atrazine disrupts meiosis and normal follicle formation in female mice. Sci. Rep. 7:3526. doi: 10.1038/s41598-017-03738-1

George, N. M. (2000). Evaluation on mutagenic effects of the three heavy metals on Vicia faba plants. Cytologia 65, 75-82. doi: 10.1508/cytologia.65.75

Golet, E. M., Strehler, A., Alder, A. C., and Giger, W. (2002). Determination of fluoroquinolone antibacterial agents in sewage sludge and sludge-treated soil using accelerated solvent extraction followed by solid-phase extraction. Anal. Chem. 74, 5455-5462. doi: 10.1021/ac025762m

Goulas, A., Haudin, C. S., Bergheaud, V., Dumeny, V., Ferhi, S., Nelieu, S., et al. (2016). A new extraction method to assess the environmental availability of ciprofloxacin in agricultural soils amended with exogenous organic matter. Chemosphere 165, 460-469. doi: 10.1016/j.chemosphere.2016.09.040

Grant, V. (1953). Cytogenetics of the hybrid Gilia millefoliata $\times$ achilleaefolia. Chromosoma 5, 372-390. doi: 10.1007/BF01271494

Griffing, B., and Langridge, J. (1963). Factors affecting crossing over in the tomato. Aust. J. Biol. Sci. 16, 826-837. doi: 10.1071/BI9630826

Hamscher, G., Sczesny, S., Höper, H., and Nau, H. (2002). Determination of persistent tetracycline residues in soil fertilized with liquid manure by highperformance liquid chromatography with electrospray ionization tandem mass spectrometry. Anal. Chem. 74, 1509-1518. doi: 10.1021/ac015588m

Hanson, W. (1961). Effect of calcium and phosphorus nutrition on genetic recombination in the soybean. Crop Sci. 1, 384-384. doi: 10.2135/cropscil961. 0011183X000100050033x

Hautier, Y., Tilman, D., Isbell, F., Seabloom, E., Borer, E., and Reich, P. (2015). Anthropogenic environmental changes affect ecosystem stability via biodiversity. Science 348, 336-340. doi: 10.1126/science.aaa1788

Heberer, T. (2002). Tracking persistent pharmaceutical residues from municipal sewage to drinking water. J. Hydrol. 266, 175-189. doi: 10.1016/S0022-1694(02) 00165-8

Higgins, J. D., Perry, R. M., Barakate, A., Ramsay, L., Waugh, R., Halpin, C., et al. (2012). Spatiotemporal asymmetry of the meiotic program underlies the predominantly distal distribution of meiotic crossovers in barley. Plant Cell 24, 4096-4109. doi: 10.1105/tpc.112.102483

Hossain, M. G. (1978). Effects of external environmental factors on chromosome pairing in autotetraploid rye. Cytologia 43, 21-34. doi: 10.1508/cytologia. 43.21

Hulskotte, J. H. J., Denier van der Gon, H. A. C., Visschedijk, A. J. H., and Schaap, M. (2007). Brake wear from vehicles as an important source of diffuse copper pollution. Water Sci. Technol. 56, 223-231. doi: 10.2166/wst.2007.456

International Plant Protection Convention [IPPC] (2014). Climate Change 2014: Synthesis Report. Contribution of Working Groups I, II and III to the Fifth Assessment Report of the Intergovernmental Panel on Climate Change. Geneva: IPCC.

Jensen, J. (1981). Effects of temperature on genetic recombination in barley. Hereditas 94, 215-218. doi: 10.1111/j.1601-5223.1981.tb01755.x

Jones, R. A. (2016). Future scenarios for plant virus pathogens as climate change progresses. Adv. Virus Res. 95, 87-147. doi: 10.1016/bs.aivir.2016.02.004

Karihaloo, J. L. (1986). Stress induced desynapsis in Hemerocallis. Cytologia 51, 193-199. doi: 10.1508/cytologia.51.193
Karihaloo, J. L. (1994). Genotype-environment interaction in the desynapsis of a Hemerocallis 'Sleeping Beauty' clone and its progeny. Cytologia 59, 483-491. doi: 10.1508/cytologia.59.483

Kathiria, P., Sidler, C., Golubov, A., Kalischuk, M., Kawchuk, L. M., and Kovalchuk, I. (2010). Tobacco Mosaic Virus infection results in an increase in recombination frequency and resistance to viral, bacterial, and fungal pathogens in the progeny of infected tobacco plants. Plant Physiol. 153, 1859-1870. doi: 10.1104/pp.110.157263

Kaul, B. L. (1968). A study of meiosis in virus infected Datura quarcifolia. Cytologia 33, 17-20. doi: 10.1508/cytologia.33.17

Kaymak, F. (2005). Cytogenetic effects of maleic hydrazide on Helianthus annuus L. Pak. J. Biol. Sci. 8, 104-108. doi: 10.3923/pjbs.2005.104.108

Khan, S., Cao, Q., Zheng, Y. M., Huang, Y. Z., and Zhu, Y. G. (2008). Health risks of heavy metals in contaminated soils and food crops irrigated with wastewater in Beijing, China. Environ. Pollut. 152, 686-692. doi: 10.1016/j.envpol.2007.06.056

Koti, S., Reddy, K. R., Reddy, V. R., Kakani, V. G., and Zhao, D. (2005). Interactive effects of carbon dioxide, temperature, and ultraviolet-B radiation on soybean (Glycine max L.) flower and pollen morphology, pollen production, germination, and tube lengths. J. Exp. Bot. 56, 725-736. doi: 10.1093/jxb/eri044

Kovalchuk, I., Kovalchuk, O., Kalck, V., Boyko, V., Filkowski, J., Heinlein, M., et al. (2003). Pathogen-induced systemic plant signal triggers DNA rearrangements. Nature 423, 760-762. doi: 10.1038/nature01683

Kristen, U. (1997). Use of higher plants as screens for toxicity assessment. Toxicol. In Vitro 11, 181-191. doi: 10.1016/S0887-2333(97)00005-2

Kuchy, A., Wani, A., and Kamili, A. (2016). Cytogenetic effects of three commercially formulated pesticides on somatic and germ cells of Allium cepa. Environ. Sci. Pollut. R. 23, 6895-6906. doi: 10.1007/s11356-015-5912-6

Kumar, G. (2007). Comparative genotoxic potential of mercury and cadmium in soybean. Turk. J. Biol. 31, 13-18.

Kumar, G., and Rai, P. K. (2010). The genotoxic potential of two heavy metals in inbred lines of maize (Zea mays). Turk. J. Bot. 34, 39-46.

Kumar, G., and Ritambhara, T. (2006). Individual and combined effects of lead and gamma irradiations on genetic recombination in Lathyrus sativus. J. Phytol. Res. 19, 215-220.

Kumar, U., and Sinha, S. S. N. (1991). Genotoxic effects of two pesticides (Rogor and Bavistin) and an antibiotic (Streptomycin) in meiotic cells of grasspea (Lathyrus sativus L.). Cytologia 56, 209-214. doi: 10.1508/cytologia.56.209

Kumar Ravindra, P. (2017). Studies on pollen viability of papaya (Carica papaya) infected by Papaya Ring Spot Virus (PRSV). Int. J. Adv. Res. 5, 1664-1667. doi: 10.21474/IJAR01/4585

Küster, A., and Adler, N. (2014). Pharmaceuticals in the environment: scientific evidence of risks and its regulation. Philos. Trans. R. Soc. B 369:20130587. doi: $10.1098 /$ rstb.2013.0587

Lakshmi, N., Prakash, N., and Harini, I. (1988). Cytological effects of agricultural chemicals I. effects of insecticides "Ekalux and Metasystox" on chilli (Capsicum annuum L.). Cytologia 53, 703-708. doi: 10.1508/cytologia.53.703

Law, C. (1963). An effect of potassium on chiasma frequency and recombination. Genetica 33, 313-329. doi: 10.1007/BF01725768

Lee, H. B., Peart, T. E., and Svoboda, M. L. (2007). Determination of ofloxacin, norfloxacin, and ciprofloxacin in sewage by selective solid-phase extraction, liquid chromatography with fluorescence detection, and liquid chromatography-tandem mass spectrometry. J. Chromatogr. A 1139, 45-52. doi: 10.1016/j.chroma.2006.11.068

Lee, K., Rao, G., Barnett, F., and Liang, G. (1974). Further evidence of meiotic instability induced by Atrazine in grain-sorghum. Cytologia 39, 697-702. doi: 10.1508/cytologia.39.697

Liang, G. H., Feltner, K., and Russ, O. (1969). Meiotic and morphological response of grain sorghum to atrazine, 2, 4-D, oil, and their combinations. Weed Sci. 17, 8-12.

Lin, Y. J. (1982). Temperature and chiasma formation in Rhoeo spathacea var. variegata. Genetica 60, 25-30. doi: 10.1007/BF00121453

Lloyd, A., Morgan, C., Franklin, C., and Bomblies, K. (2018). Plasticity of meiotic recombination rates in response to temperature in Arabidopsis. Genetics 208, 1409-1420. doi: 10.1534/genetics.117.300588

Lucht, J. M., Mauch-Mani, B., Steiner, H. Y., Metraux, J. P., Ryals, J., and Hohn, B. (2002). Pathogen stress increases somatic recombination frequency in Arabidopsis. Nat. Genet. 30, 311-314. doi: 10.1038/ng846 
Ma, T.-H., Anderson, V. A., and Ahmed, I. (1982). "Environmental clastogens detected by meiotic pollen mother cells of Tradescantia," in Genotoxic Effects of Airborne Agents, eds Tice, R. Raymond, Daniel, Schaich, and M. Karen (Boston, MA: Springer), 141-157.

Ma, T.-H., and Harris, M. (1987a). Tradescantia micronucleus (Trad-MCN) assay - a potential indoor pollution monitor. Environ. Mutagen. 9(Suppl.):8.

Ma, T.-H., and Harris, M. (1987b). "Tradescantia micronucleus (Trad-MCN) bioassay- a promising indoor air pollution monitoring system," in Proceedings of the 4th International Conference on Indoor Air Quality and Climate, Berlin, 243-247.

Ma, T.-H., Van Anderson, A., and Sandhu, S. S. (1980). “A preliminary study of the clastogenic effects of diesel exhaust fumes using the tradescantia micronucleus bioassay," in Short-Term Bioassays in the Analysis of Complex Environmental Mixtures II, eds M. Waters, S. Nesnow, J. L. Huisingh, S. S. Sandhu, and L. Claxton (Boston, MA: Springer), 351-358.

Mann, S. K. (1977). Cytological and genetic effects of dithane fungicides on Allium cepa. Environ. Exp. Bot. 1977, 7-12. doi: 10.1016/0098-8472(77)90014-4

Mann, S. K. (1978). Interaction of tetracycline (TC) with chromosomes in Allium cepa. Environ. Exp. Bot. 18, 201-205. doi: 10.1016/0098-8472(78)90039-4

Martín, A. C., Rey, M.-D., Shaw, P., and Moore, G. (2017). Dual effect of the wheat $\mathrm{Ph} 1$ locus on chromosome synapsis and crossover. Chromosoma 126, 669-680. doi: 10.1007/s00412-017-0630-0

Mason, A. S., and Pires, J. C. (2015). Unreduced gametes: meiotic mishap or evolutionary mechanism? Trends Genet. 31, 5-10. doi: 10.1016/j.tig.2014.09.011

Mickelbart, M. V., Hasegawa, P. M., and Bailey-Serres, J. (2015). Genetic mechanisms of abiotic stress tolerance that translate to crop yield stability. Nat. Rev. Genet. 16, 237-251. doi: 10.1038/nrg3901

Mittal, N., and Srivastava, A. K. (2014). Cadmium and chromium induced aberrations in the reproductive biology of Hordeum vulgare. Cytologia 79, 207-214. doi: 10.1508/cytologia.79.207

Modliszewski, J. L., and Copenhaver, G. P. (2017). Meiotic recombination gets stressed out: CO frequency is plastic under pressure. Curr. Opin. Plant Biol. 36, 95-102. doi: 10.1016/j.pbi.2016.11.019

Modliszewski, J. L., Wang, H., Albright, A. R., Lewis, S. M., Bennett, A. R., Huang, J., et al. (2018). Elevated temperature increases meiotic crossover frequency via the interfering (Type I) pathway in Arabidopsis thaliana. PLoS Genet. 14:e1007384. doi: 10.1371/journal.pgen.1007384

Molinier, J., Ries, G., Zipfel, C., and Hohn, B. (2006). Transgeneration memory of stress in plants. Nature 442, 1046-1049. doi: 10.1038/nature05022

Moss, B. (2008). Water pollution by agriculture. Philos. Trans. R. Soc. Lond. B Biol. Sci. 363, 659-666. doi: 10.1098/rstb.2007.2176

Namuco, O. S., and O'Toole, J. C. (1986). Reproductive stage water stress and sterility. I. Effect of stress during meiosis I. Crop Sci. 26, 317-321. doi: 10.2135/ cropsci1986.0011183X002600020022x

Naveedullah, Hashmi, M. Z., Yu, C., Shen, H., Duan, D., Shen, C., et al. (2013). Risk assessment of heavy metals pollution in agricultural soils of siling reservoir watershed in Zhejiang province, China. Biomed. Res. Int. 2013:590306. doi: $10.1155 / 2013 / 590306$

Noedler, K., Licha, T., and Voutsa, D. (2013). Twenty years later - Atrazine concentrations in selected coastal waters of the Mediterranean and the Baltic Sea. Mar. Pollut. Bull. 70, 112-118. doi: 10.1016/j.marpolbul.2013.02.018

Omidi, M., Siahpoosh, M. R., Mamghani, R., and Modarresi, M. (2014). The influence of terminal heat stress on meiosis abnormalities in pollen mother cells of wheat. Cytologia 79, 49-58. doi: 10.1508/cytologia.79.49

Pandey, R. (2017). Studies on pollen viability of papaya (Carica papaya) infected by papaya ring spot virus (prsv). Int. J. Adv. Res. 5, 1664-1667. doi: 10.21474/ IJAR01/4585

Pecrix, Y., Rallo, G., Folzer, H., Cigna, M., Gudin, S., and Le Bris, M. (2011). Polyploidization mechanisms: temperature environment can induce diploid gamete formation in Rosa sp. J. Exp. Bot. 62, 3587-3597. doi: 10.1093/jxb/ err052

Phillips, D., Jenkins, G., Macaulay, M., Nibau, C., Wnetrzak, J., Fallding, D., et al. (2015). The effect of temperature on the male and female recombination landscape of barley. New Phytol. 208, 421-429. doi: 10.1111/nph.13548

Powell, J. B., and Nilan, R. A. (1963). Influence of temperature on crossing over in an inversion heterozygote in barley. Crop Sci. 3, 11-13. doi: 10.2135/ cropsci1963.0011183X000300010005x
Prakash, N., Lakshmi, N., and Harini, I. (1988). Cytological effects of agricultural chemicals. II. Effects of fungicides" Bavistin" and" Deltan" on chilli (Capsicum annuum L.). Cytologia 53, 709-715. doi: 10.1508/cytologia.53.709

Prakken, R. (1943). Studies of asynapsis in rye. Hereditas 29, 475-495. doi: 10.1111/ j.1601-5223.1943.tb03301.x

Qi, W., Müller, B., Pernet-Coudrier, B., Singer, H., Liu, H., Qu, J., et al. (2014). Organic micropollutants in the Yangtze River: seasonal occurrence and annual loads. Sci. Total Environ. 472, 789-799. doi: 10.1016/j.scitotenv.2013.11.019

Rahavi, M. R., Migicovsky, Z., Titov, V., and Kovalchuk, I. (2011). Transgenerational adaptation to heavy metal salts in Arabidopsis. Front. Plant Sci. 2:91. doi: 10.3389/fpls.2011.00091

Razu, M., Zaman, S., Akhter, R., Rahman, M., Rahaman, M. H., Mazid, M., et al. (2014). Morphological and cytological effects of two herbicides on tetraploid wheat (Triticum durum L.). J. Biosci. 20, 143-151.

Reddy, S. S., and Rao, G. M. (1981). Cytogenetic effects of agricultural chemicals I. Effects of insecticides" BHC and nuvacron" on chromosomal mechanism in relation to yield and yield components in chilli (Capsicum annuum L.). Cytologia 46, 699-707. doi: 10.1508/cytologia.46.699

Rey, M. D., Martin, A. C., Smedley, M., Hayta, S., Harwood, W., Shaw, P., et al. (2018). Magnesium increases homoeologous crossover frequency during meiosis in ZIP4 (Ph1 gene) mutant wheat-wild relative hybrids. Front. Plant Sci. 9:509. doi: 10.3389/fpls.2018.00509

Rezaei, M., Arzani, A., and Sayed-Tabatabaei, B. E. (2010). Meiotic behaviour of tetraploid wheats (Triticum turgidum L.) and their synthetic hexaploid wheat derivates influencedby meiotic restitution and heat stress. J. Genet. 89, 401-407. doi: 10.1007/s12041-010-0058-2

Robinson, B. H., Bischofberger, S., Stoll, A., Schroer, D., Furrer, G., Roulier, S., et al. (2008). Plant uptake of trace elements on a Swiss military shooting range: uptake pathways and land management implications. Environ. Pollut. 153, 668-676. doi: 10.1016/j.envpol.2007.08.034

Rodrigues, G. S., Ma, T. H., Pimentel, D., and Weinstein, L. H. (1997). Tradescantia bioassays as monitoring systems for environmental mutagenesis: a review. Crit. Rev. Plant Sci. 16, 325-359. doi: 10.1080/07352689709701953

Rodrigues, G. S., Madkour, S. A., and Weinstein, L. H. (1996). Genotoxic activity of ozone in Tradescantia. Environ. Exp. Bot. 36, 45-50. doi: 10.1016/00988472(95)00042-9

Rowan, B. A., Oldenburg, D. J., and Bendich, A. J. (2010). RecA maintains the integrity of chloroplast DNA molecules in Arabidopsis. J. Exp. Bot. 61, 2575-2588. doi: 10.1093/jxb/erq088

Saini, H. S., Sedgley, M., and Aspinall, D. (1984). Developmental anatomy in wheat of male sterility induced by heat stress, water deficit or abscisic acid. Aust. J. Plant Physiol. 11, 243-253. doi: 10.1071/PP9840243

Shan, Y., Tysklind, M., Hao, F., Ouyang, W., Chen, S., and Lin, C. (2013). Identification of sources of heavy metals in agricultural soils using multivariate analysis and GIS. J. Soils Sedim. 13, 720-729. doi: 10.1007/s11368-012-0637-3

Sharma, C., Behera, B. N., Raju, D. S. S., and Rao, B. G. S. (1983). Effects of some systemic fungicides on the chiasma frequencies in Hordeum vulgare. Cytologia 48, 749-752. doi: 10.1508/cytologia.48.749

Sharma, C., Patra, B., Raju, D. S. S., and Murty, K. V. (1981). Chiasma variation in Hordeum vulgare after exposure to herbicides. Mutat. Res. 91, 333-336. doi: 10.1016/0165-7992(81)90010-5

Sharma, C. B. S., and Panneerselvam, N. (1990). Genetic toxicology of pesticides in higher-plant systems. Crit. Rev. Plant Sci. 9, 409-442. doi: 10.1016/j.mrfmmm. 2016.08.003

Si, W., Yuan, Y., Huang, J., Zhang, X., Zhang, Y., Zhang, Y., et al. (2015). Widely distributed hot and cold spots in meiotic recombination as shown by the sequencing of rice F2 plants. New Phytol. 206, 1491-1502. doi: 10.1111/nph. 13319

Singh, N., and Srivastava, A. (2014). Biomonitoring of genotoxic effect of glyphosate and pendimethalin in Vigna mungo populations. Cytologia 79, 173-180. doi: 10.1508/cytologia.79.173

Skazkin, F. D., and Zavadskaya, I. G. (1957). On the influence of soil moisture deficiency and nitrogen nutrition on microsporogenesis in barley. Dokl Akad Nauk SSSR 117, 240-242.

Soriano, J. D. (1984). Herbicide-induced chromosomal aberrations and inheritance of a digenic seedling mutation in sorghum. Cytologia 49, 201-207. doi: 10.1508/ cytologia. 49.201 
Srivastava, N., and Kumar, G. (2016). Effect of waterlogging stress on meiotic course, tetrad formation and pollen fertility of Sesbania pea. Cytol. Genet. 50, 36-39. doi: 10.3103/S0095452716010096

Stapley, J., Feulner, P., Johnston, S., Santure, A., and Smadja, C. (2017). Variation in recombination frequency and distribution across eukaryotes: patterns and processes. Philos. T. R. Soc. B. 372:20160455. doi: 10.1098/rstb.2016.0455

Swaminathan, M. S., Ninan, T., and Magoon, M. L. (1959). Cytological effects of mosaic virus in chillis. Genetica 30, 63-69. doi: 10.1007/BF01535665

Thiele-Bruhn, S. (2003). Pharmaceutical antibiotic compounds in soils - a review. J. Plant Nutr. Soil Sci. 166, 145-167. doi: 10.1002/jpln.200390023

Tian, M., Liu, Y., Zhang, Y., Kang, X., and Zhang, P. (2018). High temperature exposure did not affect induced $2 \mathrm{n}$ pollen viability in Populus. Plant Cell Environ. 41, 1383-1393. doi: 10.1111/pce.13165

Tilman, D., Cassman, K. G., Matson, P. A., Naylor, R., and Polasky, S. (2002). Agricultural sustainability and intensive production practices. Nature 418, 671-677. doi: 10.1038/nature01014

Tornero, V., and Hanke, G. (2016). Chemical contaminants entering the marine environment from sea-based sources: a review with a focus on European seas. Mar. Pollut. Bull. 112, 17-38. doi: 10.1016/j.marpolbul.2016.06.091

Trebicki, P., Dader, B., Vassiliadis, S., and Fereres, A. (2017). Insect-plant-pathogen interactions as shaped by future climate: effects on biology, distribution, and implications for agriculture. Insect Sci. 24, 975-989. doi: 10.1111/1744-7917. 12531

Tripathi, R., and Girjesh, K. (2010). Genetic loss through heavy metal induced chromosomal stickiness in grass pea. Caryologia 63, 223-228. doi: 10.1080/ 00087114.2010 .10589731

Uslu, M. O., Jasim, S., Arvai, A., Bewtra, J., and Biswas, N. (2013). A survey of occurrence and risk assessment of pharmaceutical substances in the Great Lakes basin. Ozone Sci. Eng. 35, 249-262. doi: 10.1080/01919512.2013.79 3595

van Tol, N., Rolloos, M., van Loon, P., and van der Zaal, B. J. (2018). MeioSeed: a CellProfiler-based program to count fluorescent seeds for crossover frequency analysis in Arabidopsis thaliana. Plant Methods 18, 14-32. doi: 10.1186/s13007018-0298-3

Vanneste, K., Baele, G., Maere, S., and Van de Peer, Y. (2014). Analysis of 41 plant genomes supports a wave of successful genome duplications in association with the Cretaceous-Paleogene boundary. Genome Res. 24, 1334-1347. doi: $10.1101 /$ gr.168997.113

Verde, L. A. (2003). The Effect of Stress on Meiotic Recombination in Maize (Zea mays L). Ph.D. thesis, Iowa State University, Ames, IA.

Vonberg, D., Hofmann, D., Vanderborght, J., Lelickens, A., Koeppchen, S., Puetz, T., et al. (2014). Atrazine soil core residue analysis from an agricultural field 21 years after its ban. J. Environ. Qual. 43, 1450-1459. doi: 10.2134/ jeq2013.12.0497

Wang, J., Daili Li, D., Shang, F., and Kang, X. (2017). High temperature-induced production of unreduced pollen and its cytological effects in Populus. Nat. Sci. Rep. 7:5281. doi: 10.1038/s41598-017-05661-x

Wang, X., and Copenhaver, G. P. (2018). Meiotic recombination: mixing it up in plants. Annu. Rev. Plant Biol. 69, 13.11-13.33. doi: 10.1146/annurev-arplant042817-040431

Williams, C. F., and McLain, J. E. (2012). Soil persistence and fate of carbamazepine, lincomycin, caffeine, and ibuprofen from wastewater reuse. J. Environ. Qual. 41, 1473-1480. doi: 10.2134/jeq2011.0353
Wilson, J. Y. (1959a). Chiasma frequency in relation to temperature. Genetica 29, 290-303. doi: 10.1007/BF01535715

Wilson, J. Y. (1959b). Temperature effect on chiasma frequency in the bluebell Endymion nonscriptus. Chromosoma 10, 337-354. doi: 10.1007/BF00396577

Wuu, K. (1967). Chromosomal aberrations induced by pesticides in meiotic cells of barley. Cytologia 32, 31-41. doi: 10.1508/cytologia.32.31

Wuu, K., and Grant, W. (1966). Induced abnormal meiotic behavior in a barley plant (Hordeum vulgare L) with herbicide Lorox. Phyton 23:63.

Xu, X., Zhao, Y., Zhao, X., Wang, Y., and Deng, W. (2014). Sources of heavy metal pollution in agricultural soils of a rapidly industrializing area in the Yangtze Delta of China. Ecotoxicol. Environ. Saf. 108, 161-167. doi: 10.1016/j.ecoenv. 2014.07.001

Yao, Y., Kathiria, P., and Kovalchuk, I. (2013). A systemic increase in the recombination frequency upon local infection of Arabidopsis thaliana plants with oilseed rape mosaic virus depends on plant age, the initial inoculum concentration and the time for virus replication. Front. Plant Sci. 4:61. doi: $10.3389 /$ fpls.2013.00061

Yelina, N., Diaz, P., Lambing, C., and Henderson, I. R. (2015). Epigenetic control of meiotic recombination in plants. Sci. China Life Sci. 58, 223-231. doi: 10.1007/ s11427-015-4811-x

Zhang, H., Zhou, Y., Huang, Y., Wu, L., Liu, X., and Luo, Y. (2016). Residues and risks of veterinary antibiotics in protected vegetable soils following application of different manures. Chemosphere 152, 229-237. doi: 10.1016/j.chemosphere. 2016.02.111

Zhang, M.-K., Liu, Z.-Y., and Wang, H. (2010). Use of single extraction methods to predict bioavailability of heavy metals in polluted soils to rice. Commun. Soil Sci. Plant 41, 820-831. doi: 10.1080/00103621003592341

Zhang, S., Li, X., Sun, Z., Shao, S., Hu, L., Ye, M., et al. (2015). Antagonism between phytohormone signalling underlies the variation in disease susceptibility of tomato plants under elevated CO2. J. Exp. Bot. 66, 1951-1963. doi: 10.1093/ jxb/eru538

Zheng, T., Nibau, C., Phillips, D. W., Jenkins, G., Armstrong, S. J., and Doonan, J. H. (2014). CDKG1 protein kinase is essential for synapsis and male meiosis at high ambient temperature in Arabidopsis thaliana. Proc. Natl. Acad. Sci. U.S.A. 111, 2182-2187. doi: 10.1073/pnas.1318460111

Ziolkowski, P. A., Underwood, C. J., Lambing, C., Martinez-Garcia, M., Lawrence, E. J., Ziolkowska, L., et al. (2017). Natural variation and dosage of the HEI10 meiotic E3 ligase control Arabidopsis crossover recombination. Genes Dev. 31, 306-317. doi: 10.1101/gad.295501.116

Zohair, S., Khatoon, S., and Zaidi, S. (2012). Cytological studies on 14 plant species under polluted conditions. Pak. J. Bot. 44, 1977-1982.

Conflict of Interest Statement: The authors declare that the research was conducted in the absence of any commercial or financial relationships that could be construed as a potential conflict of interest.

Copyright (c) 2018 Fuchs, Jenkins and Phillips. This is an open-access article distributed under the terms of the Creative Commons Attribution License (CC BY). The use, distribution or reproduction in other forums is permitted, provided the original author(s) and the copyright owner(s) are credited and that the original publication in this journal is cited, in accordance with accepted academic practice. No use, distribution or reproduction is permitted which does not comply with these terms. 